\title{
Latent Class Analysis: a new vision of the phenomenon of depression in elderly men in the Brazilian Northeast
}

Rita de Cássia Hoffmann Leão $0^{\top}$

Vanessa de Lima Silva ${ }^{1}$

Rafael da Silveira Moreira'

\section{Abstract}

Objective: to identify the prevalence of depression in elderly men and associated factors using Latent Class Analysis. Method: a cross-sectional, epidemiological study evaluating 162 Primary Care users resident in the community in Recife, Brazil, was carried out. The Yesavage Geriatric Depression Scale was used as a screening instrument. The study was based on descriptive analysis and Latent Class Analysis, which allows the indirect measurement of the phenomenon of Depression by measuring the latent phenomenon of depression through 15 directly observed questions/answers from the scale used followed by ordinal logistic regression. Results: Elderly men with up to four years of schooling had a 2.43 times greater chance of developing depression. Those with normal levels of cortisol were less likely to become depressed while elderly men with low levels of Vitamin D and testosterone and high levels of thyroid stimulating hormones (TSH) were more likely to be depressed. The prevalence of the highest level of depression in the study population was $29 \%$ and was associated with low levels of education and alterations in the clinical data investigated. Conclusion: The study concluded that Latent Class Analysis allowed an innovative perspective of the phenomenon of depression and its relationship with associated factors, allowing a better and broader approach to this phenomenon in clinical practice.

\footnotetext{
Universidade Federal de Pernambuco, Centro de Ciências da Saúde, Programa de Pós-Graduação em Gerontologia. Recife, Pernambuco, Brasil

Correspondence

Rita de Cássia Hoffmann Leão

ritachl@yahoo.com.br
}

Keywords: Men's Health. Elderly. Depression. Epidemiology. Logistic Models. 


\section{INTRODUCTION}

In the 1990s the World Health Organization (WHO) considered depression to be the fourth leading cause of social disability among diseases. It is expected that by 2012 it will become the second leading cause of disability in developed countries and the main cause of this condition in developing countries. It is estimated that the disorder will be the leading pathology of the global disease burden by $2030^{1}$.

In Brazil, according to Ministry of Health data, the prevalence of depression is higher among women, ranging from $3 \%$ to $11 \%$ of the population, representing a significant public health problem ${ }^{2}$. It is worth noting that among the elderly, symptoms of depression may be related to socioeconomic, cultural and biological factors ${ }^{3}$. The high prevalence of depression among this group requires special attention due to its direct and indirect impact on the health of individuals. Improved diagnosis rates, the early identification of cases and a more effective approach to depressive disorders in Primary Care involves systematic screening ${ }^{4}$. This demonstrates the need for a wider investigation as such conditions have their own characteristics, and untreated depression in patients with preexisting diseases tends to have a longer or recurrent course $e^{5}$. The proportion of individuals with depression, as well as the severity of the condition, increases proportionally with advancing age, and is less frequent among men ${ }^{6}$.

Although depression affects both genders, studies show that there is a lower prevalence of this disorder among men. There is controversy about this finding, however, as there is a difference between the number of men and women who seek health services ${ }^{7}$. One possible explanation may come from the cultural characteristics of gender relations, as women seek treatment for their health problems more frequently and express their feelings more often ${ }^{4}$.

Depression is the most common psychiatric illness which leads to suicide, and the elderly are the age group which most often commit suicide. It is estimated that the majority $(75 \%)$ of people who commit suicide consult with their doctors in the month and between one-third and one-half in the week prior to their deaths for reasons other than depression. The majority of first depressive episodes are undiagnosed and therefore untreated ${ }^{2}$.

When accompanied by suicidal ideation, depression is a risk factor that justifies immediate and preventive measures. A greater number of ways to diagnose and assertively treat depression in the elderly is required ${ }^{8}$. Psychiatric disorders, and more specifically depression, are clearly the most important risk factors. Socio-environmental factors, such as lifestyle and social isolation, should also not be ignored?

Research specifically involving the topic of depression in the elderly male population remains rare. And as this population is not culturally accustomed to seeking outpatient care in Preventive Medicine, there is a need for greater knowledge.

This study aims to identify the prevalence of and factors associated (socioeconomic, demographic, morbidity and clinical-laboratory) with depression in elderly men treated in Primary Care.

\section{METHOD}

A cross-sectional epidemiological study was carried out in a Family Health Centre (FHC) in Sanitary District VIII, in Recife, Pernambuco, from June to September 2015.

The FHC features three teams and covers an area with 2,699 registered families and approximately 6,300 users.

The study population was formed by male elderly residents in the areas covered by the micro-areas of the three teams in the community of Jordão Alto. Elderly persons were considered those who at the time of data collection were aged 60 years or more, as stipulated by Brazilian Legislation. A total of 224 individuals were identified with these characteristics.

The study was carried out based on population census, without the use of a sample. Elderly men living in the community of Jordão Alto were included, without cognitive deficits or deficiencies that impeded their understanding and ability to respond to the questionnaire. Caregivers could be 
present but could not participate in the interview responses. In the case of illiterate elderly persons, the reading of the FICF was performed by the interviewer and signed by fingerprint. Data collection was performed by means of a questionnaire and analysis of the patient's medical records (which included morbidity and clinical-laboratory data). The evaluation began with the Mini Mental State Exam (which was used as an exclusion criterion in case of moderate or severe cognitive impairment) and the Yesavage Geriatric Depression Scale with 15 questions.

The interviews were carried out at the Jordão Alto Health Center, in the Medical Treatment Room, or in the patient's home (in a private space) in the case of elderly people who could not visit the Health Center, with only the researcher and the interviewee (and their caregiver, when necessary) present, regardless of the chosen location. The users were selected during previously scheduled routine appointments and through invitation to attend the Health Center, delivered by Community Health Agents, during home visits.

Laboratory data was recorded from information taken from medical records. The Health Center laboratory collections are routinely performed when requested during consultations at the center itself. The results were analyzed according to laboratory reference values, in accordance with the guidelines of the Brazilian society of endocrinology and metabolism.

The reduced Yesavage Geriatric Depression Scale (GDS 15) ${ }^{10}$ was used for screening of depressive symptomatology and the Mini Mental State Examination (MMSE) was applied as the exclusion criterion in case of cognitive impairment. The MMSE is one of the main and most frequently used instruments for cognitive evaluation, mainly among the elderly, and is recommended for the screening of cognitive deficit. It was decided to use the original cutoff point of $23^{11}$. It is known that the MMSE is influenced by several factors, notably schooling. Because of this, the use of varied cutoff points, appropriate to the different educational levels of the study population, is recommended ${ }^{12}$. To date, however, there is no consensus regarding cut-off points for cognitive decline in Brazil. Schooling has received special attention, being the subject of analyzes carried out with different samples, aimed mainly at the suitability of these cut-off points ${ }^{13}$. A questionnaire elaborated by the authors was also applied, containing questions about social, economic, demographic factors, morbidities and clinical information.

The instrument selected for the screening of Depression in this study was the Yesavage Geriatric Depression Scale with 15 items (EDG 15) 10, which is widely used and validated as a diagnostic tool for depression in elderly patients. These items, taken together, exhibited good diagnostic accuracy, with adequate sensitivity, specificity and reliability ${ }^{14}$.

Although the use of the Geriatric Depression Scale is recommended by the Brazilian Ministry of Health in Primary Care, its routine application only occurs in local contexts. The inclusion of such screening can provide early and more accurate diagnoses and interventions, as well as result in lower costs for the health system ${ }^{4}$.

During the aging process, functional capacity can be impaired by incapacitating and psychosomatic diseases, which lead to physical inactivity, social isolation, affect quality of life and can be a risk factor for death'. The socioeconomic-demographic, morbidity and clinical questionnaire was elaborated with the objective of evaluating the association of these factors with the depressive symptomatology.

The socioeconomic variables, demographic variables, morbidities and those related to the hormonal profile of the subjects were considered as independent. The morbidities studied were considered those most frequently exhibited by users in Primary Care, such as Cardiovascular Diseases, Rheumatic Diseases, Diabetes Mellitus and Cancer.

The dependent variable was chosen to characterize the concept of depression in the participants. GDS $15^{15}$ was used, which is a test for the detection of depressive symptoms in the elderly consisting of 15 questions (affirmative or negative), where the result is the sum of responses: 0 - when the answer is different from the example in parentheses and 1 - when the answer is the same as the example in brackets. The cutoff points and classification according to the sum of these points are: score of $0-4$ points (absence of suspicion of depression); between $5-11$ points 
(suspicion of depression); equal to or greater than 12 points (characterizes depression). The variable is therefore composed of 15 questions whose answers are categorical and dichotomous (Yes or No), ranging from zero to fifteen points ${ }^{10,15}$.

However, considering: a) the limitations that cutoff points impose on the analysis and the impossibility of ensuring that people with the same score would have answered the same questions in a similar way; b) the complexity of the subject (Depression) and the difficulty of directly measuring and observing the same, and c) that the 15 questions of the instrument are strategies to indirectly measure something that is difficult to grasp in a single direct measure, Latent Class Analysis (LCA) was chosen as an evaluation technique. This is a latent phenomenon (not observed directly) but is indirectly measured by the 15 directly observed questions/answers of the scale used. Latent Class Analysis is a statistical method that identifies distinct groups (latent classes) based on the patterns of responses observed in categorical variables. This method investigates whether the relationship of covariance among a group of observable variables is explained by another latent variable (class) ${ }^{16}$.

A descriptive analysis was performed, according to the nature of the presented variables. After the latent variable "depression" was created, it was used as a response variable (dependent). The strength of association between the independent variables and the response variable was expressed by the Odds Ratio (OR) with a confidence interval of $95 \%$. For the calculation of the Odds Ratio, ordinal logistic regression, also called the proportional odds model, was used. Simple and multiple analyzes were performed. In the simple analysis, variables that obtained a $p$-value $<0.25$ were elective for multiple analysis. For the multiple regression the forward method was used and the other conclusions were considered at a significance level of $5 \%$.

In terms of the blocks of analysis, the variables were classified according to Figure 1.

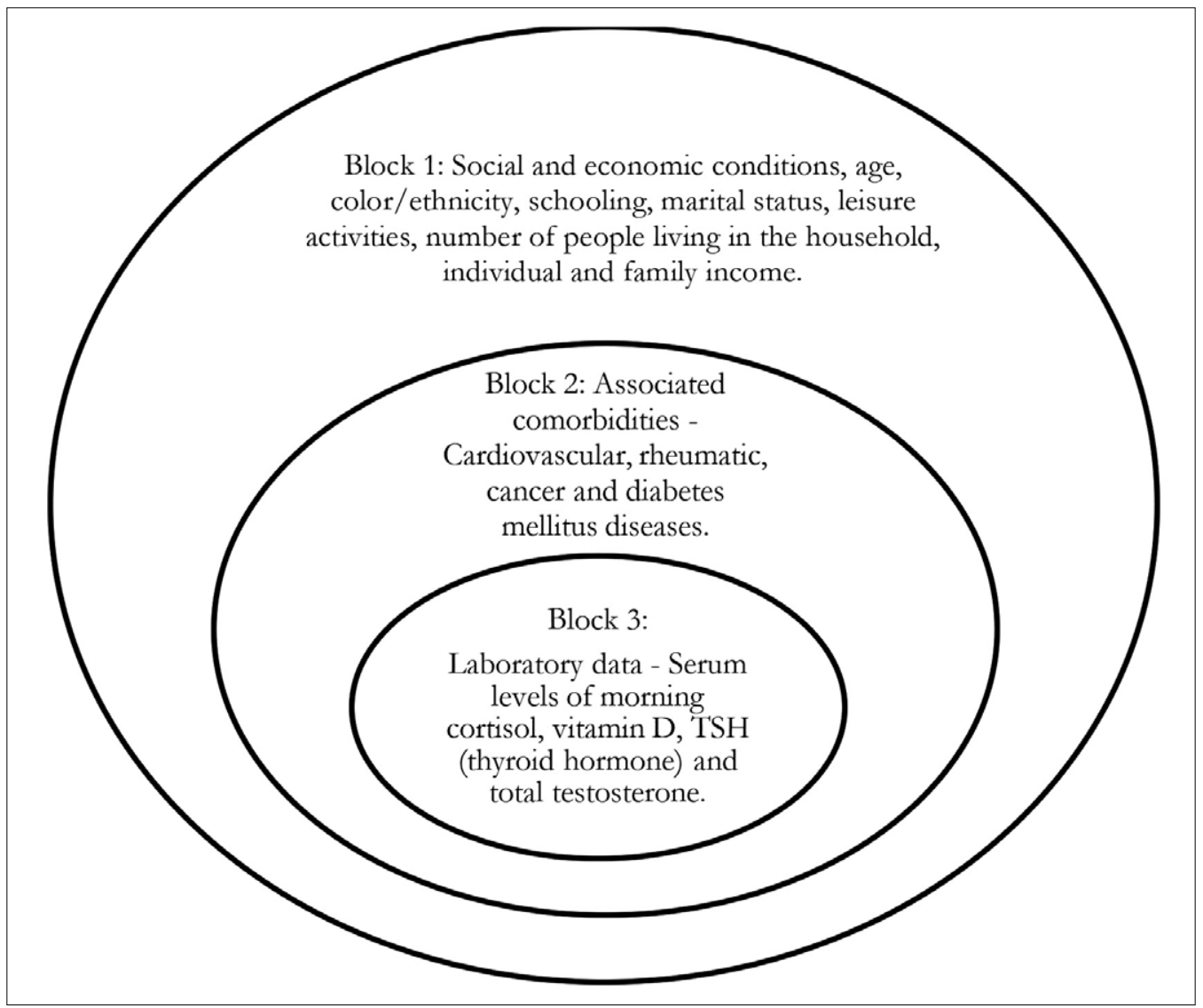

Figure 2. Absolute and relative frequency by class. Recife, Pernambuco, 2015. 
The Project was approved by the Research Ethics Committee of the Universidade Federal de Pernambuco (Federal University of Pernambuco), under approval number 1,076,173, according to resolution 466/12 on research with human beings. The interview was conducted following consent and the reading and signing of the FICF by the participants, and authorization of the letter of agreement from Recife City Council for access to users.

\section{RESULTS}

From a total of 224 elderly men registered with and receiving care at the Health Center, 36 users were rejected based on the exclusion criteria and 26 were not found at their address during the survey. A total of 162 elderly persons aged between 60 and 102 years were therefore interviewed. The median age was 69 years (interquartile Intervals from 64 to 78 years) and the Caucasian/white population totaled $26.5 \%$. The median age position did not interfere with the extreme values.

It was found that approximately $83 \%$ of the respondents had a low level of schooling (1 to 4 years) and 15\% had studied for five years or more. Regarding marital status, $68 \%$ were married, $6 \%$ were single and $26 \%$ were separated or widowed.
In an initial analysis of the results obtained in the Geriatric Depression Scale (GDS), the following profiles were observed: $37 \%$ of the elderly interviewed had a score between zero and four, with no suspicion of depression; $58.6 \%$ had scores between 5 and 11 (suspicion of depression) and $4.4 \% \mathrm{had}$ scores between 12 and 15, and so were considered to have a diagnosis of depression, according to the established classification ${ }^{12}$. However, such cut-off points include, for example, individuals who scored 5 and those who scored 11 in the same category, with the former probably more likely to be included in the category with no suspicion of depression, and the latter, who scored 11, more predisposed to a diagnosis of depression.

Figure 2 therefore shows the absolute and relative frequency of each class as well as the names for each, according to the result obtained by LCA. Four distinct classes with greater parsimony were observed. Such distribution reveals a similar proportion (about 29\%) at the extremes (Happy and Motivated, Depressed and Hopeless). In intermediate positions were 14.8\% of discouraged but motivated elderly, and $26.5 \%$ who were considered as bored and helpless.

Table 1 shows the probabilities of belonging to each latent class according to the answer (Yes or No) given to each of the 15 questions in the GDS questionnaire.

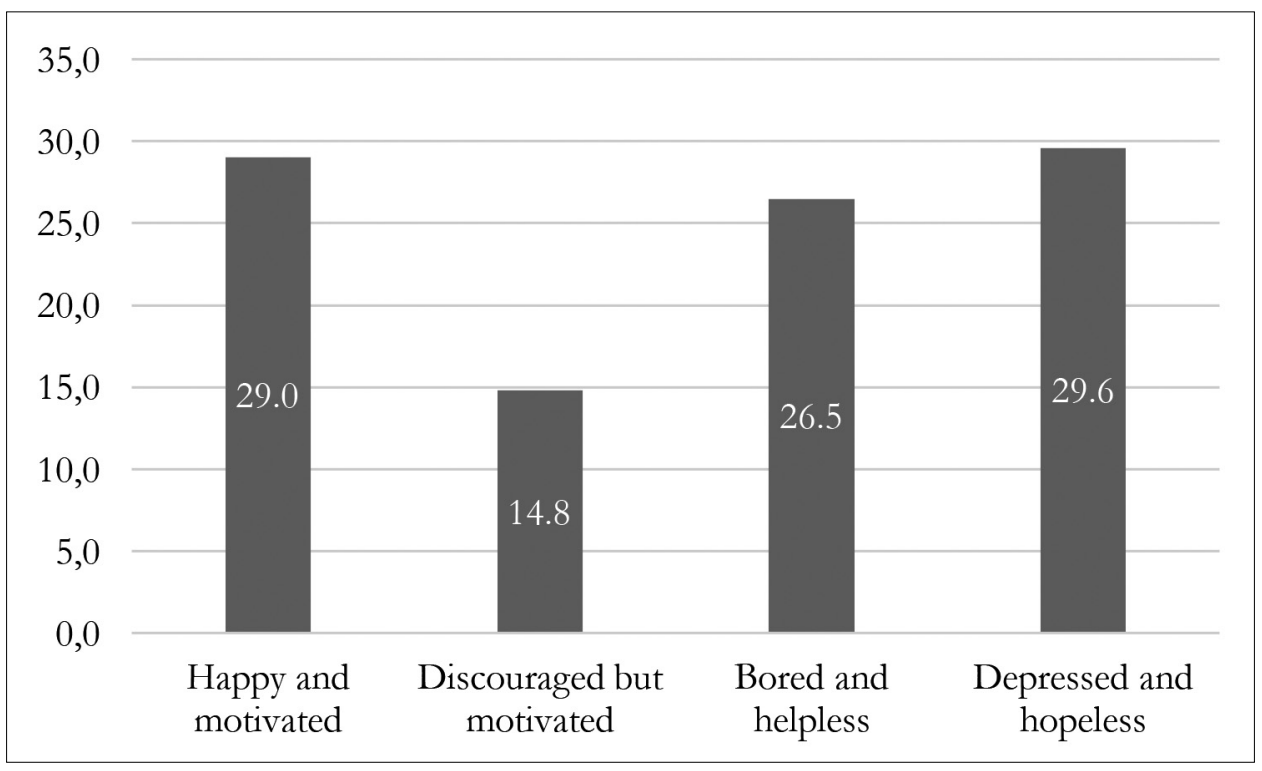

Figure 2. Absolute and relative frequency by class. Recife, Pernambuco, 2015. 
Table 1. Discrimination among four latent classes generated and response probability for the 15 questions of the GDS. Recife, Pernambuco, 2015.

\begin{tabular}{|c|c|c|c|c|}
\hline Latent Classes & $\begin{array}{l}\text { Happy and } \\
\text { motivated }\end{array}$ & $\begin{array}{l}\text { Discouraged } \\
\text { but motivated }\end{array}$ & $\begin{array}{l}\text { Bored and } \\
\text { helpless }\end{array}$ & $\begin{array}{l}\text { Depressed } \\
\text { and hopeless }\end{array}$ \\
\hline Are you basically satisfied with your life? & 18.60 & 84.70 & 73.40 & 100.00 \\
\hline Have you dropped many of your activities and interests? & 91.20 & 100.00 & 100.00 & 100.00 \\
\hline Do you feel that your life is empty? & 0.00 & 20.30 & 54.00 & 100.00 \\
\hline Do you often get bored? & 43.00 & 85.40 & 100.00 & 86.50 \\
\hline Are you in good spirits most of the time? & 2.20 & 0.00 & 27.00 & 78.80 \\
\hline $\begin{array}{l}\text { Are you afraid that something bad is going } \\
\text { to happen to you? }\end{array}$ & 9.80 & 84.50 & 84.70 & 97.80 \\
\hline Do you feel happy most of the time? & 4.60 & 100.00 & 0.00 & 100.00 \\
\hline Do you often feel helpless? & 38.50 & 33.20 & 100.00 & 72.80 \\
\hline $\begin{array}{l}\text { Do you prefer to stay at home, rather than going out } \\
\text { and doing new things? }\end{array}$ & 82.50 & 92.40 & 100.00 & 100.00 \\
\hline $\begin{array}{l}\text { Do you feel you have more problems with memory } \\
\text { than most? }\end{array}$ & 6.60 & 47.60 & 13.50 & 40.50 \\
\hline Do you think it is wonderful to be alive now? & 0.00 & 0.00 & 9.00 & 28.50 \\
\hline Do you feel pretty worthless the way you are now? & 0.00 & 0.00 & 11.20 & 30.60 \\
\hline Do you feel full of energy?? & 42.90 & 100.00 & 93.30 & 100.00 \\
\hline Do you feel that your situation is hopeless? & 0.00 & 0.00 & 4.50 & 39.40 \\
\hline $\begin{array}{l}\text { Do you think that most people are better off } \\
\text { than you are? }\end{array}$ & 86.80 & 100.00 & 100.00 & 89.10 \\
\hline
\end{tabular}

Created by the authors.

It can be seen in Table 1 that there are three questions whose responses were very similar for the four classes. Dropping most activities and interests, preferring to stay home instead of going out and doing new things, and thinking that many others are better off may be common perceptions in older people, from the most motivated to the most depressed. They do not therefore clearly and effectively discriminate a state of depression and could not be included in the sum of a score, even less so with the same weight as the other questions.

The chi-squared test (Table 2) revealed an association between the two forms of classification, while analysis of the standardized residuals showed that there was a higher than expected count (standardized residuals greater than 1.96 at a significance level of 5) between the extreme classifications of the presence and absence of depression, where the agreement was $100 \%$ The two intermediate latent classes coincided with the classification of suspicion of depression of the GDS scale, but with distinct profiles in these borderline areas of the extremes.

Table 2 shows that there is greater agreement between individuals who were classified as without depression by the GDS (as Happy and Motivated) and those with Depression (as Depressed and Hopeless). There is an intermediate zone that the GDS classifies as Suspicion of Depression, where when only the scores are considered, the subtlety of the class profile is lost. Regarding GDS specificity and sensitivity, Table 2 demonstrates the agreement between the LCA and the GDS. It was not the aim of this study to compare LCA to a gold standard for the screening or diagnosis of Depression, but to help an already validated instrument improve the definition of its categories. 
Table 2. Association between two forms of Depression Classification Chi-squared test and Standardized Residuals Analysis. Recife, Pernambuco, 2015.

\begin{tabular}{|c|c|c|c|c|c|}
\hline \multirow[b]{2}{*}{ Latent Class Analysis } & & \multicolumn{3}{|c|}{ GDS Analysis* } & \multirow[t]{2}{*}{ Total } \\
\hline & & $\begin{array}{l}\text { Without } \\
\text { depression }\end{array}$ & $\begin{array}{l}\text { Suspicion of } \\
\text { depression }\end{array}$ & Depressed & \\
\hline \multirow[t]{4}{*}{ Happy and motivated } & $\mathrm{n}$ & 22 & 25 & 0 & 47 \\
\hline & $\%$ Line & 46.80 & 53.20 & 0.00 & 100.00 \\
\hline & $\%$ Column & 100.00 & 21.60 & 0.00 & 29.00 \\
\hline & $\begin{array}{l}\text { Standardized } \\
\text { Residual }\end{array}$ & 7.9 & -3.3 & -3.4 & \\
\hline \multirow[t]{4}{*}{ Discouraged but motivated } & $\mathrm{n}$ & 0 & 24 & 0 & 24 \\
\hline & $\%$ Line & 0.00 & 100.00 & 0.00 & 100.00 \\
\hline & $\%$ Column & 0.00 & 20.70 & 0.00 & 14.80 \\
\hline & $\begin{array}{l}\text { Standardized } \\
\text { Residual }\end{array}$ & -2.1 & 3.3 & -2.2 & \\
\hline \multirow[t]{4}{*}{ Bored and helpless } & $\mathrm{n}$ & 0 & 43 & 0 & 43 \\
\hline & $\%$ Line & 0.00 & 100.00 & 0.00 & 100.00 \\
\hline & $\%$ Column & 0.00 & 37.10 & 0.00 & 26.50 \\
\hline & $\begin{array}{l}\text { Standardized } \\
\text { Residual }\end{array}$ & -3 & 4.8 & -3.2 & \\
\hline \multirow[t]{4}{*}{ Depressed and hopeless } & $\mathrm{n}$ & 0 & 24 & $\underline{24}$ & 48 \\
\hline & $\%$ Line & 0.00 & 50.0 & 50.00 & 100.00 \\
\hline & $\%$ Column & 0.00 & $20.70 \%$ & 100.00 & 29.60 \\
\hline & $\begin{array}{l}\text { Standardized } \\
\text { Residual }\end{array}$ & -3.3 & -4 & 8.2 & \\
\hline \multirow[t]{4}{*}{ Total } & $\mathrm{n}$ & 22 & 116 & 24 & 162 \\
\hline & \% Line & 13.60 & 71.60 & 14.80 & 100.00 \\
\hline & $\%$ Column & 100.00 & 100.00 & 100.00 & 100.00 \\
\hline & $\%$ do Total & 13.60 & 71.60 & 14.80 & 100.00 \\
\hline
\end{tabular}

*Chi-squared test $(p<0.05)$; GDS - Geriatric Depression Scale

The results of the simple and multiple ordinal logistic regression models in each block are shown in Table 3. The $p$ value and the $95 \%$ Confidence Interval (CI) were estimated by the
Wald test. Multiple analysis reveals similar results, highlighting level of schooling and laboratory data as factors associated with Depression in the study population. 
Table 3. Results for depression from the simple and multiple models of ordinal logistic regression. Recife, Pernambuco, 2015.

\begin{tabular}{|c|c|c|c|c|c|c|c|c|}
\hline \multirow{3}{*}{$\begin{array}{l}\text { Independent variables } \\
\text { of each block }\end{array}$} & \multicolumn{4}{|c|}{ Simples } & \multicolumn{4}{|c|}{ Multiple } \\
\hline & \multirow[t]{2}{*}{ OR } & \multicolumn{2}{|c|}{ CI 95\% } & \multirow[t]{2}{*}{$p$-value } & \multirow[t]{2}{*}{ OR } & \multicolumn{2}{|c|}{ CI 95\% } & \multirow{2}{*}{$p$-value } \\
\hline & & $\operatorname{Inf}$ & Sup & & & Inf & Sup & \\
\hline \multicolumn{9}{|l|}{ Block 1} \\
\hline Age $<$ median $(69)$ & 1.00 & & & & & & & \\
\hline Age $\geq$ median (69) & $\mid 1.37$ & 0.78 & 2.39 & 0.265 & & & & \\
\hline Caucasians & 1.00 & & & & & & & \\
\hline Non-Caucasians & $\mid 1.49$ & 0.78 & 2.83 & 0.225 & & & & \\
\hline No schooling & 1.97 & 0.87 & 4.43 & 0.100 & 1.90 & 0.76 & 4.70 & 0.166 \\
\hline Up to 4 years of schooling & 1.74 & 0.79 & 3.82 & 0.167 & 2.43 & 1.01 & 5.89 & 0.048 \\
\hline 5 years or more of schooling & $\mid 1.00$ & & & & 1.00 & & & \\
\hline Individual income $<$ median 790 & 1.20 & 0.67 & 2.14 & 0.529 & & & & \\
\hline Renda individual $\geq$ median 790 & 1.00 & & & & & & & \\
\hline Renda familiar $<$ median-1580 & 1.08 & 0.62 & 1.88 & 0.788 & & & & \\
\hline Renda familiar $\geq$ median-1580 & $\mid 1.00$ & & & & & & & \\
\hline Leisure activities & 1.00 & & & & & & & \\
\hline No leisure activities & 1.50 & 0.86 & 2.62 & 0.152 & & & & \\
\hline N.people/room<median 2 & 1.45 & 0.77 & 2.73 & 0.239 & & & & \\
\hline N.people/room $\geq$ median 2 & 1.00 & & & & & & & \\
\hline Single & 1.00 & & & & & & & \\
\hline Married & 2.21 & 0.64 & 7.58 & 0.206 & & & & \\
\hline Separated or widowed & 2.28 & 0.61 & 8.45 & 0.218 & & & & \\
\hline \multicolumn{9}{|l|}{ Block 2} \\
\hline Heart disease & 1.23 & 0.65 & 2.32 & 0.522 & & & & \\
\hline Without heart disease & $\mid 1.00$ & & & & & & & \\
\hline Rheumatologic diseases & 0.97 & 0.53 & 1.77 & 0.920 & & & & \\
\hline Without rheumatologic diseases & $\mid 1.00$ & & & & & & & \\
\hline Diabetes & 0.86 & 0.47 & 1.57 & 0.625 & & & & \\
\hline Without diabetes & 1.00 & & & & & & & \\
\hline Cancer & 0.82 & 0.21 & 3.16 & 0.775 & & & & \\
\hline Without cancer & 1.00 & & & & & & & \\
\hline \multicolumn{9}{|l|}{ Block 3} \\
\hline Low Vitamin D level & 14.14 & 6.18 & 32.32 & $<0.001$ & 10.33 & 4.06 & 26.27 & $<0.001$ \\
\hline Normal Vitamin D level & $\mid 1.00$ & & & & 1.00 & & & \\
\hline Low TSH level * & 1.00 & & & & 1.00 & & & \\
\hline Normal TSH level & 3.68 & 0.34 & 39.45 & 0.280 & 11.31 & 0.97 & 131.98 & 0.053 \\
\hline High TSH level & | 12.10 & 1.10 & 132.53 & 0.041 & 15.73 & 1.30 & 189.95 & 0.030 \\
\hline Low cortisol level & 1.00 & & & & 1.00 & & & \\
\hline Normal cortisol level & 0.26 & 0.14 & 0.50 & $<0.001$ & 0.34 & 0.17 & 0.69 & 0.003 \\
\hline High cortisol level & 0.53 & 0.23 & 1.17 & 0.120 & 0.55 & 0.22 & 1.37 & 0.200 \\
\hline Low testosterone level & 7.73 & 3.89 & 15.36 & $<0.001$ & 3.24 & 1.41 & 7.42 & 0.005 \\
\hline Normal testosterone level & 1.00 & & & & 1.00 & & & \\
\hline
\end{tabular}

${ }^{*} \mathrm{TSH}=$ Thyroid stimulating hormone 
Regarding level of schooling, it can be affirmed that the elderly with no schooling have a $90 \%$ chance (though not significant) of developing depressive symptoms, while those with up to 4 years of schooling have a 2.43 times greater chance of developing depression than those with 5 years or more of schooling. Analysis of the laboratory data revealed that low serum levels of vitamin D and testosterone were associated with depression in the elderly persons, and that high or normal levels of TSH also contributed to a predisposition to depression in these individuals. Normal levels of serum cortisol "protect" the individual, giving a $66 \%$ chance of not developing depressive symptoms.

\section{DISCUSSION}

It is important to fully understand the physiological, biochemical and social changes that elderly individuals suffer during the aging process to meet the specific needs of this age group. Depression in the elderly is considered a secondary illness in relation to chronic diseases, and may be related to the end of one's professional career, the onset of chronic diseases and abandonment by relatives ${ }^{17}$.

The fact that men report fewer depressive symptoms contributes to the erroneous idea that depressive disorders affect the male gender less. In recent years, the number of men hospitalized for depression has increased, according to a study carried out in a medium-sized philanthropic psychiatric care hospital in Minas Gerais ${ }^{18}$.

It was observed in the present study that both clinical data and schooling had significant and independent effects on depression. Older people with no education were $90 \%$ more likely to become depressed, while the chances of developing depression were 2.43 times greater in those with up to 4 years of schooling than those with 5 years or more of schooling. Another study carried out with the elderly population in the south of Brazil ${ }^{19}$, showed that those with a lower educational level had a statistically higher mean $(p<0.05)$ of depressive symptoms. In a cross-sectional study conducted by Brischiliari ${ }^{20}$ to assess CNCD, it was shown that such symptoms were more prevalent in elderly and in individuals with low educational levels, a fact also evidenced in a study by Paula et al. ${ }^{21}$ which found that depressive symptomatology was more evident among younger elderly people, women and the less educated. In terms of the clinical-laboratory data of this study, four relevant factors were observed in relation to the interviewed public: 1) the elderly with normal levels of cortisol are $66 \%$ less likely to become depressed; 2 ) those with hypovitaminosis $\mathrm{D}$ had a 10 times greater chance of suffering from depression; 3 ) those with low total testosterone levels tend to be 2.24 times more likely to become depressed; 4) those with high TSH levels were 15 times more likely to become depressed.

Vitamin D also plays an important role in depression. It has been revealed that depression is strongly associated with lower serum levels of Vitamin D, even after adjusting for age, gender, body mass index, smoking, health status, physical activity level and level of urbanization ${ }^{22}$.

The geriatric population is more sensitive to hypovitaminosis $\mathrm{D}$. This occurs for several reasons, both due to the inadequate intake of vitamin $\mathrm{D}$, reduced exposure to the sun and the interference of polypharmacy in the metabolism of the vitamin ${ }^{23}$. A study conducted in Australia that sought to explore the association between serum levels of Vitamin D and a wide variety of health conditions to identify an optimal range for vitamin D concentrations, found that in men aged 70 years this level was between 50.0 and $74.9 \mathrm{nmol} / \mathrm{l}$, with no additional benefits associated with levels above this ${ }^{24}$.

In this study, those with high serum levels of thyroid stimulating hormone (TSH) had a 15-fold greater chance of developing depressive symptoms than elderly patients with low serum levels of $\mathrm{TSH}^{25}$. The association between depression and frank hypothyroidism has been described in scientific literature. The incidence of hypothyroidism increases after 60 years, often ranging from $0.5 \%$ to $5 \%$ in cases of frank hypothyroidism and $15 \%$ to $20 \%$ in cases of subclinical hypothyroidism. Thyroid hormone concentrations are associated with the severity of depression and may have an impact on the final clinical outcome ${ }^{26}$.

To diagnosis hypothyroidism, however, it is necessary to evaluate other thyroid hormones, although the association in this study between TSH and predisposition to depression was statistically significant. 
The population of this study with normal levels of the hormone Cortisol had a $66 \%$ greater chance of not developing depressive symptoms than individuals with low level of this hormone.

The population analyzed in this study with low levels of total testosterone (when compared to normal levels) had a 2.24 times greater chance of developing depression, corroborating studies by other authors in which psychological factors were related to low testosterone levels in men from an age group identical to that of our study population ${ }^{27,28}$.

The screening instrument used was GDS-15. It was observed that three questions (dropped many activities and interests, prefer to stay at home, rather than going out and doing new thing, think that most people are better off) may be part of the reality of many elderly, without necessarily representing depressive symptomatology, and may reflect their socioeconomic or family situation, similar to that observed in another study ${ }^{29}$. These questions have the same weight as others aimed more directly at the diagnosis of depression, which makes the analysis more fragile, especially in the cut-off points.

According to Latent Class Analyzes, four ordinal classes were created from the results obtained: happy and motivated, discouraged but motivated, bored and helpless and depressed and hopeless (with similar proportional distribution at the extremes of $29 \%$ ) for a better evaluation of results. This analysis allowed a new form of evaluation for the classification and screening of depressive symptomatology in the elderly, overcoming the typical limitations of the traditionally used cut-off points.

Bretanha et al. ${ }^{30}$ concluded in their studies that the high prevalence of depressive symptoms in the population requires investment in prevention actions, focusing on practices that promote active aging, contributing to the improvement of self-perception of health and satisfaction with life. A need to expand the present study was noted, considering the importance of psychosocial factors that may also be associated with depression and which were not considered in depth here.

Due to the cross-sectional nature of the study causal association could not be established. The limitations that cut-off points impose on the analysis and the impossibility of ensuring that people with the same score would have answered the same questions in a similar way limit the traditional approach of the instrument used.

The imposition of cutoff points for the diagnostic classification of depression remains a typical limitation of this type of measurement, especially in borderline scores between one category and another, as well as the lack of weighting between the different questions used.

In addition, depression is a complex and difficult to observe/measure object of study, and the 15 questions of the instrument are an attempt to indirectly measure something that is hard to grasp in a single direct measure. However, Latent Class Analysis (LCA) represented an innovative aspect in the discussion of this emblematic phenomenon, which is increasingly present among the elderly, but little studied from a gender perspective.

\section{CONCLUSION}

The study concluded that Latent Class Analysis represented an innovative perspective on the phenomenon of depression, revealing a prevalence of $29 \%$ in the population studied, with expressive socioeconomic, demographic and clinical associations.

Studies that propose to investigate depression in the elderly male population and its associated correlates are rare. The present study represents an opportunity for an understanding of Depression through Latent Class Analysis, in which the condition is a non-directly observed phenomenon. Meanwhile, it can be measured by a greater probability of belonging to a given response profile, taken from the Geriatric Depression Scale used.

It was therefore proposed to identify the prevalence and factors associated with depression in elderly men treated in Primary Care. The increase in the number of depressive symptoms in the studied population was associated with a low level of education and alterations in the clinical data investigated. In addition, intermediate levels of depression were observed. 
In this context, an alternative view of elderly residents in this and similar communities is extremely valuable and can support agendas and educational activities in health and investment in the improvement of health services, through the extension of gerontological knowledge for multi and interdisciplinary teams, as well as encouraging the involvement of the family and society, contributing to an early diagnosis and the application of appropriate treatment.

A new scenario has emerged in clinical practice. The perception of the signs and symptoms of depression in the elderly (as well as the observation of related variables) and especially among elderly men is a great challenge for professionals, and fundamental for the prevention of injuries and correct interventions.
The health of elderly men needs to be properly evaluated. It is essential that new studies are carried out in the geriatric-gerontological area, in order to include more such elderly men and treat them more effectively, as well as to qualify and train health teams and continuously invest in the Health Service to meet the demands of this population. A healthier and longer life expectancy can subsequently be achieved.

\section{ACKNOWLEDGEMENTS}

We would like to thank the elderly men who participated in the present study and the Post-Graduate Program in Gerontology of the Universidade Federal de Pernambuco, for supporting this research.

\section{REFERENCES}

1. World Health Organization. Global burden of mental disorders and the need for a comprehensive, coordinated response from health and social sectors at the country level: report by the Secretariat [Internet]. Geneva: WHO; 2011 [acesso em 16 set. 2015]. Disponível em: http://apps.who.int/gb/ebwha/ pdf_files/EB130/B130_R8-en.pdf

2. Brasil. Ministério da Saúde, Secretaria de atenção à saúde, Departamento de Atenção Básica.

Envelhecimento e Saúde da Pessoa Idosa. Brasília, DF: MS; 2007. (Cadernos de Atenção Básica, n. 19); (Série A. Normas e Manuais Técnicos).

3. Oliveira MF, Bezerra VP, Silva AO, Alves MSCF, Moreira MASP, Caldas CP. Sintomatologia de depressão autorreferida por idosos que vivem em comunidade. Ciênc Saúde Coletiva. 2012;17(8):2191-8.

4. Nogueira EL, Rubin LL, Giacobbo SS, Gomes I, Neto AC. Rastreamento de sintomas depressivos em idosos na Estratégia Saúde da Família, Porto Alegre. Rev Saúde Pública. 2014;48(3):368-77.

5. Sass A, Gravena AAF, Pilger C, Mathias TAF, Marcon SS. Depressão em idosos inscritos no Programa de Controle de Hipertensão Arterial e Diabetes Mellitus. Acta Paul Enferm. 2012;25(1):80-5.

6. Silva ER, Souza ARP, Ferreira LB, Peixoto HM. Prevalência e fatores associados à depressão entre idosos institucionalizados: subsídio ao cuidado de enfermagem. Rev Esc Enferm USP. 2012;46(6):1387-93
7. Justo LP, Calil HM. Depressão: o mesmo acometimento para homens e mulheres? Rev Psiquiatr Clín. 2006;33(2):74-9.

8. Cavalcante FG, Minayo MCS, Mangas RMN. Diferentes faces da depressão no suicídio em idosos. Ciênc Saúde Coletiva. 2013;18(10):2985-94.

9. Pitchot W. Le suicide chez la personne âgée. Rev Med Liege. 2014;69(5-6):390-4.

10. Sheikh JI, Yesavage JA. Geriatric depression scale (GDS): recent evidence and development of a shorter version. Clin Gerontol. 1986;5(1-2):165-73

11. Folstein MF, Folstein SE, Mchugh PR. Mini Mental State: a practical method for grading the cognitive state of patients for the clinician. J Psychiatr Res. 1975;12(3):189-98.

12. Souza JGS, Soares LA, Souza TCS, Pereira AR, Souza AGS. Miniexame do estado mental: capacidade psicométrica e formas de avaliação. Rev APS. 2014;17(1):101-5.

13. Melo DM, Barbosa AJG. O uso do Mini-Exame do Estado Mental em pesquisas com idosos no Brasil: uma revisão sistemática. Ciênc Saúde Coletiva. 2015;20(12):3865-76.

14. Paradela EMP, Lourenço RA, Veras RP. Validação da escala de depressão geriátrica em um ambulatório geral. Rev Saúde Pública. 2005;39(6):918-23. 
15. Yesavage JA. Development and validation of a geriatric depression screening scale: a preliminary report. J Psychiatr Res. 1983;17(1):37-49.

16. Silva Junior CA. Epidemiologia dos subtipos de depressão: análise de classes latentes dos sintomas depressivos em uma amostra populacional da região Metropolitana de São Paulo [tese na Internet]. São Paulo: Universidade de São Paulo, Faculdade de Medicina; 2012 [acesso em 01 dez. 2016]. Disponível em: http://www.teses.usp.br/teses/ disponiveis/5/5142/tde-01102012-162421/

17. Almeida MASO, Lemes AG, Nascimento VF, Fonseca PIMN, Rocha EM, Volpato RJ, et al. Fatores de risco associados à depressão em idosos no interior de Mato Grosso. Rev Baiana Saúde Pública [Internet]. 2015 [acesso em 26 jun. 2016];39(3):62741. Disponível em: http://rbsp.sesab.ba.gov.br/index. $\mathrm{php} / \mathrm{rbsp} /$ article/view/1895/1263

18. Silva AG, Silva JJ, Salomé HS, Machado RM. Depressão masculina: um estudo sobre as internações na região centro-oeste de Minas Gerais. Rev Enferm UFSM. 2012;2(2):275-81.

19. Gazalle FK, Lima MS, Tavares BF, Hallal PC. Sintomas depressivos e fatores associados em população idosa no Sul do Brasil. Rev Saúde Pública. 2004;38(3):365-71.

20. Brischiliari SCR, Agnolo CMD, Gravena AAF, Lopes TCR, Carvalho MDB, Pelloso SM. Doenças crônicas não transmissíveis e associação com fatores de risco. Rev Bras Cardiol. 2014;27(1):536-7.

21. Paula AFM, Ribeiro LHM, D’ Eboux MJ, Guariento ME. Avaliação da capacidade funcional, cognição e sintomatologia depressiva em idosos atendidos em ambulatório de Geriatria. Rev Bras Clin Med. 2013;11(3):212-8.

22. Hoogendijk WJG, Lips P, Dik MG, Deeg DJH, Beekman ATF, Penninx BWJH. Depression is associated with decreased 25-Hydroxyvitamin D and increased Parathyroid Hormone levels in older adults. Arch Gen Psychiatry. 2008;65(5):508-12.
23. Fisberg RM, Marchioni DML, Castro MA, Verley Junior E, Araujo MC, Bezerra IN, et al. Ingestão inadequada de nutrientes na população de idosos do Brasil: Inquérito Nacional de Alimentação 2008-2009. Rev Saúde Pública. 2013;47(1):222-30.

24. Hirani V, Cumming RG, Naganathan V, Le Couteur DG, Handelsman DJ, Waite LM. Associations between serum 25-hydroxyvitamin D concentrations and multiple health conditions, physical performance measures, disability, and all-cause mortality: the Concord Health and Ageing in Men Project. J Am Geriatr Soc. 2014;62(3):417-25.

25. Freitas MC, Campolina AG, Ribeiro RL, Kitadai FT. Comparação de função cognitiva e depressão em pacientes hipotireoideos subclínicos com eutiroideos e hipotireoideos em tratamento, acima de 65 anos. Rev Bras Clin Med. 2009;7(2):89-94.

26. Berent D, Zboralski K, Orzechowska A, Gałecki P. Thyroid hormones association with depression severity and clinical outcome in patients with major depressive disorder. Mol Biol Reports. 2014;41(4):2419-25.

27. Shores M, Moceri M, Sloan L, Matsumoto M, Kivlahan R. Low testosterone levels predict incident depressive illness in older men: effects of age and medical morbidity. J Clin Psychiatr. 2005;66(1):7-14.

28. Mullian T, Frick M, Zuraw C, Stemhagen A, Mcwhirter C. Prevalence of hypogonadism in males aged at least 45 years: the HIM study. Int J Clin Pract. 2008;60(7):762-9.

29. Borges LJ, Benedetti TRB, Xavier AJ, D’Orsis E. Fatores associados aos sintomas depressivos em idosos: estudo Epi Floripa. Rev Saúde Pública. 2013;47(4):701-10.

30. Bretanha AF, Facchini LA, Nunes BP, Munhoz TN, Tomasi E, Thumé E. Sintomas depressivos em idosos residentes em áreas de abrangência das Unidades Básicas de Saúde da zona urbana de Bagé, RS. Rev Bras Epidemiol. 2015;18(1):1-12. 